\title{
The Impact of Electoral Cycle Occurrence on Macroeconomic Environment: Case Study of Iran
}

\author{
Hossein Amiri ${ }^{1}$ \\ | h.amiri@khu.ac.ir \\ Farzaneh Samadian ${ }^{2}$
}

\begin{abstract}
The Political business cycle theory is one of the controversial topics in modern economic theory. The political business cycle, as a political factor, influences the trends of economic variables. According to economic theories, the economic policy adopted by government before election, is an expansionary one, leading to lower taxes and unemployment; it also increases consumption per capita, GDP, and the subsidies granted by the government. However, after each election, the government adopts a restrictive policy. This paper introduces the major models used to describe and analyze political and economic cycles. Moreover, Iran's political cycles and their impact on economic development are analyzed based on the BVAR model for the period 1979-2015. According to the analysis, it is concluded that the economic variables, particularly inflation and exchange rate, are under the influence of political decisions, specifically during the election period.
\end{abstract}

Keywords: Election Period, Macro-economics Indicators, Economic Growth Rate, Unemployment Rate, Inflation, Exchange Rate.

JEL Classification: E32, P16, C32.

1. Assistant Professor Department of Economics and Islamic Banking, Faculty of Economics, University of Kharazmi, Tehran, Iran, (Corresponding Author).

2. M.A. in Economics, Faculty of Economics, University of Allameh Tabataba'i, Tehran, Iran. 


\section{تاثير وقوع ادوار انتخاباتى بر فضاى كلان

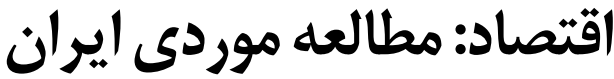

h.amiri@khu.ac.ir

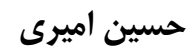

استاديار كروه آموزشى اقتصاد و بانكدارى اسلامى، دانشكده اقتصاد

دانشگاه خوارزمى، تهران، ايران (نويسنده مسئول).

فرزانه صمديان

كارشناس ارشد اقتصاد، دانشكده اقتصاد، دانشخاه علامه طباطبايى، تهران، ايران.

ج جكيده: نظريه سيكلهاى تجارى ـ سياسى يكى از موضوعهاى بحثبرانگيز نظريههاى

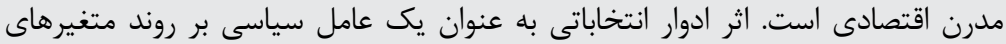

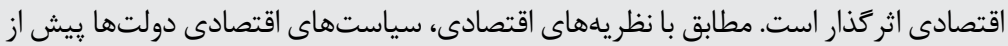

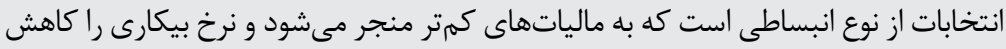

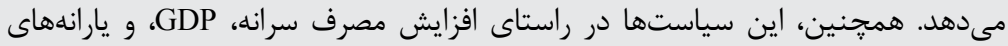

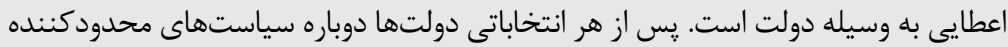

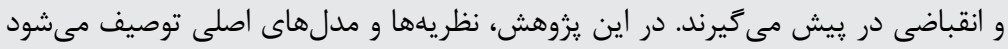

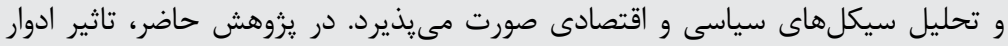

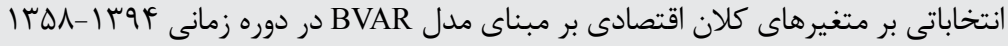

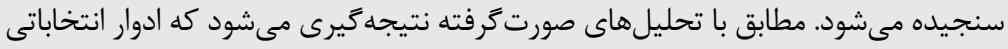

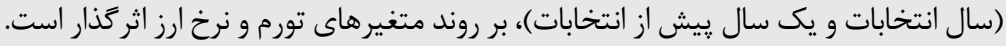

كليدوازهها: ادوار انتخاباتى، متغيرهاى كلان اقتصاد، نرخ رشد اقتصادى، نرخ بيكارى،

$$
\text { تورم، نرخ ارز. }
$$

طبقهبندى E32, P16, C32 :JEL. تورم كرن 
نوسانهاى اقتصادى در ابعاد مختلفى مىتوانند بر متغيرهاى كلان اقتصاد يك كشور اثر گذار باشند

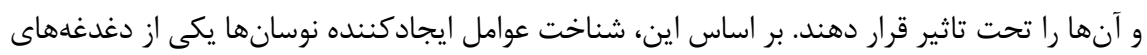
اصلى اقتصاددانان است (Persons, 1926). بخشى از مجموعه تلاشهاى انجامشده در اين زمينه سعى

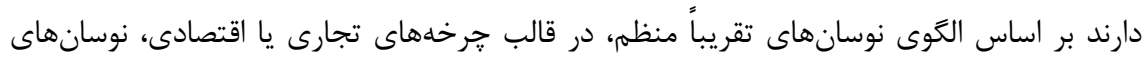

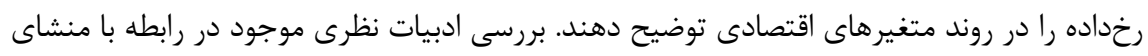

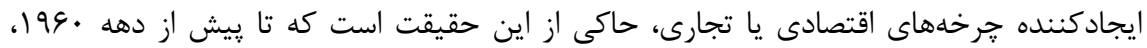
منشاى اصلى توضيحدهنده جرخههاى تجارى، از منظر علل و عوامل صِرف اقتصادى مورد تاكيد است إت إت

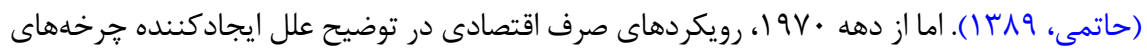

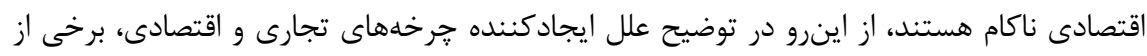

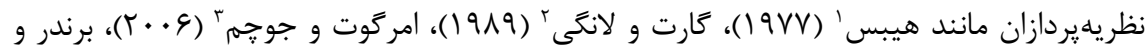

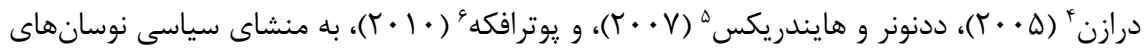
رخداده بر روند متغيرهاى اقتصاد كلان تاكيد مى كنند. نظريهيردازان اين رويكرد استدلال مى كنيند كه ادوار انتخاباتى به عنوان يك عامل سياسى، مىتواند عامل وقوع سيكلهاى اقتصادى محسوب شود.

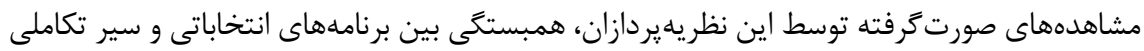

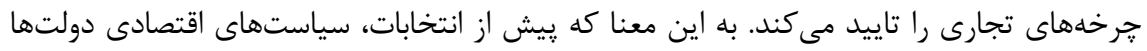

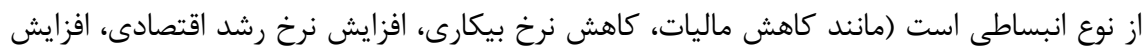

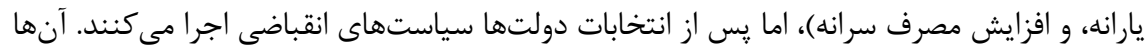

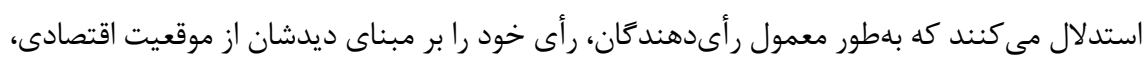

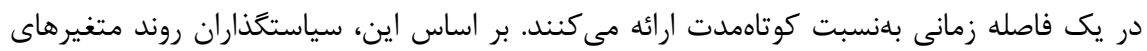
اقتصادى خود را بهَونهاى تنظيم مى كنند كه مطلوب رأى دهند مجدد ايشان بيانجامد. بديهى است كه در اين رابطه بخشها و متغيرهاى مختلف اقتصادى مى متواند

1. Hibbs

2. Garrett \& Lange

3. Immergut \& Jochem

4. Brender \& Drazen

5. De Donder \& Hindriks

6. Potrafke 
در معرض اين تعبير قرار بكيرند. توجه سياستگذاران به متغيرهاى اقتصادى در زمان انتخابات تاثير

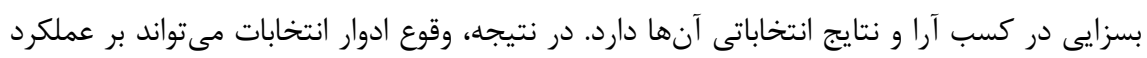
متغيرهاى اقتصادى و روند توسعه جوامع اثركذار باشد. هدف يروهش ييشارو، واكاوى تاثير وقوع ادوار انتخاباتى بر متغيرهاى كلان اقتصاد كشور است.

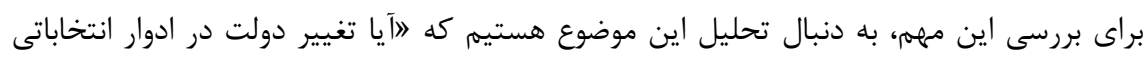

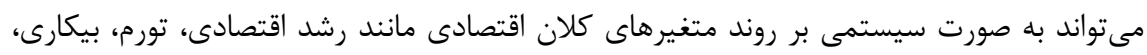

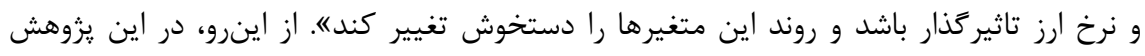
تلاش مىشود كه در قالب يك سيستم معادلههاى خودرگرسيونى به بررسى تاثير ادوار انتخاباتى

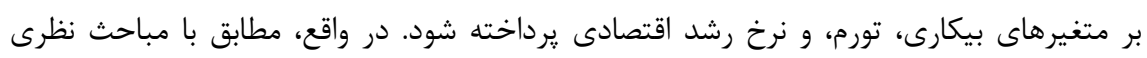

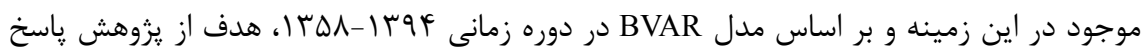

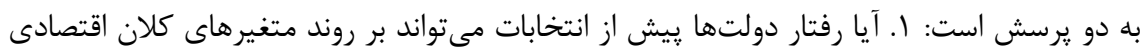
كشور موثر واقع گردد؛ و r. رفتار اقتصادى دولت در زمان نزديك به انه انتخابات بر كدام متغير كلان اقتصاد اثر بيشترى برجاى مى كذارد؟ شايان توجه است كه منظور از ادوار سياسى، سال انتخابات رياستجمهورى است. در واقع، اين يزوهش به دنبال ارزيابى اين نكته است كه در ادوار نزديك به به

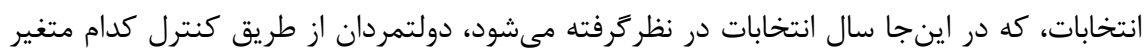

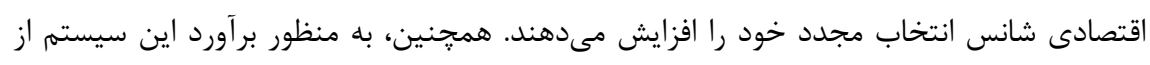
روش بيزين استفاده مىشود. يزوهش حاضر، در شش بخش سازماندهى مىشود. يس از مقدمه در بخش دوم، ادبيات موضوع

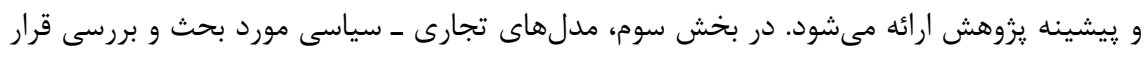

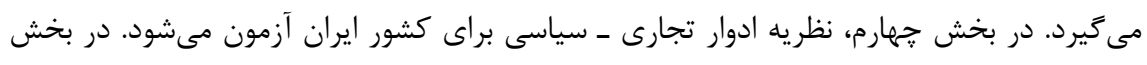

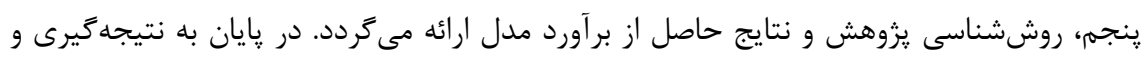
ارائه راهكارهاى اجرايى و يزوهشى در اين زمينه يرداخته ميى يُشود.

\section{مبانى نظرى يزوهش}

امروزه يزوهشهاى بينرشتهاى، از جمله مباحث اقتصاد سياسى، به يكى از مهمترين و جذابترين

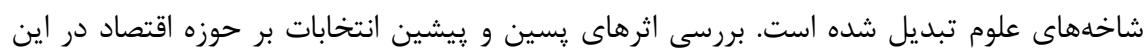

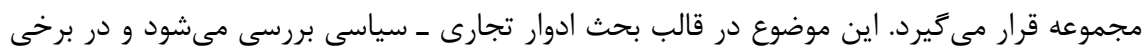


متون از آنها به عنوان ادوار انتخاباتى نام مىبرند. اصل بحث اين است كه افراد و احزاب سياسى در

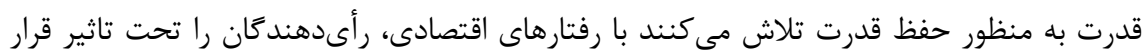
دهند. رويكرد ديكرى كه در اين رابطه وجود دارد آن است كه در ادوار انتخاباتى، تغيير دولتها با رهاي

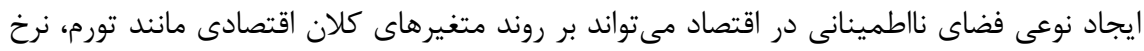

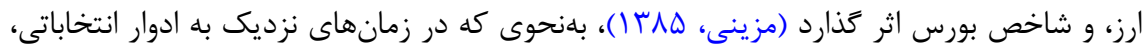
مىتوان انتظار بروز شوك بر روند متغيرهاى كلان اقتصادى را داشت.

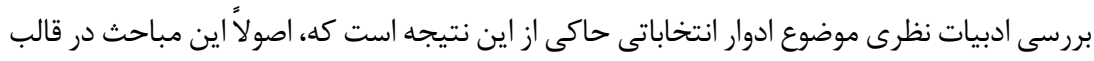

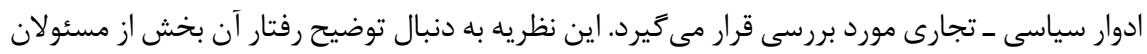

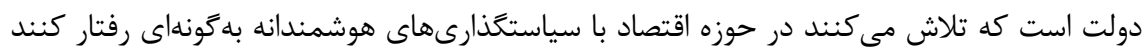

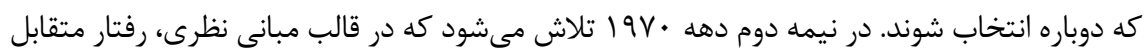
دولتمردان و رأىدهند

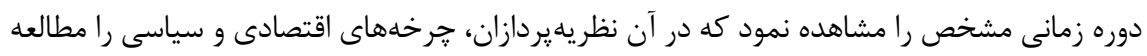

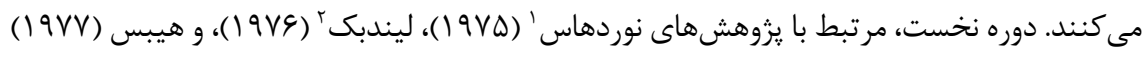

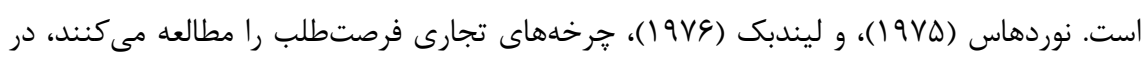

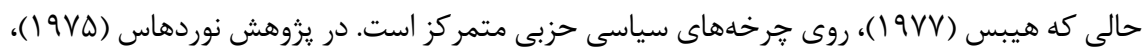

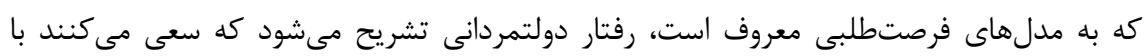

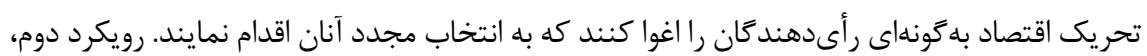

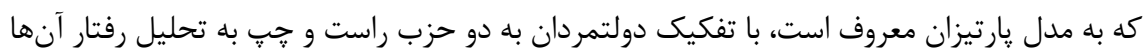

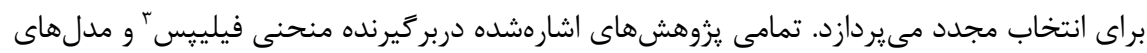

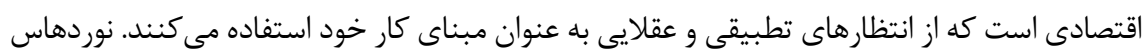

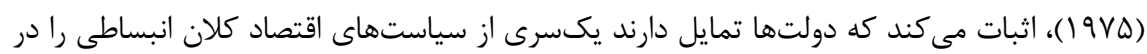
دوره پيش از انتخابات به منظور كاهش بيكارى و افزايش شانس انتخاب مجدد انجام دهند، اما هزينه

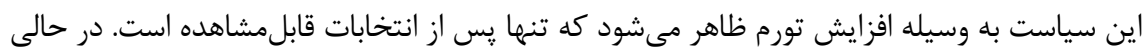

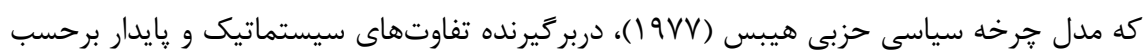

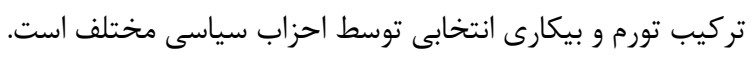

1. Nordhaus

2. Lindbeck

3. Philips Curve 


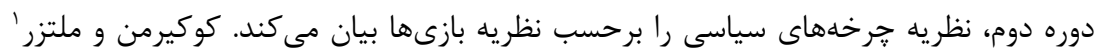

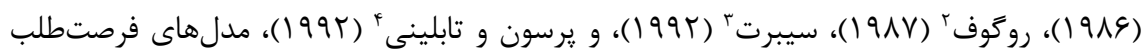

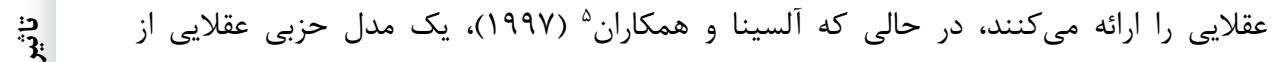

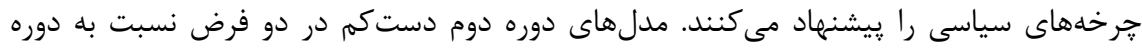

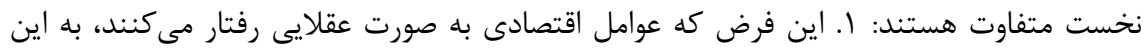

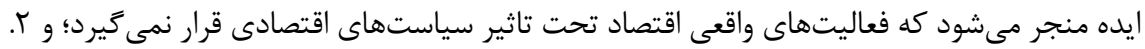

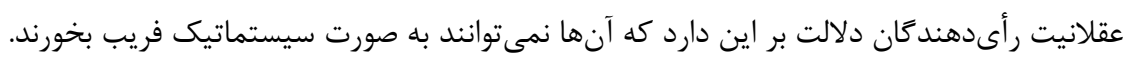

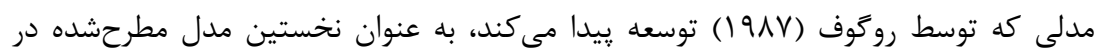

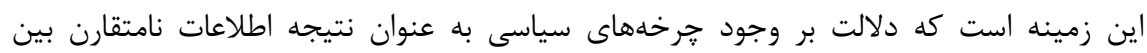

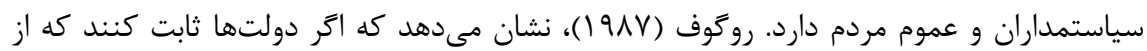

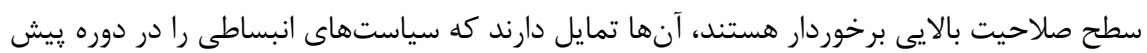

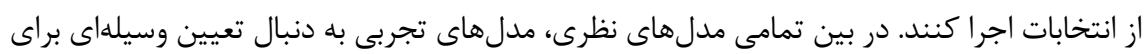

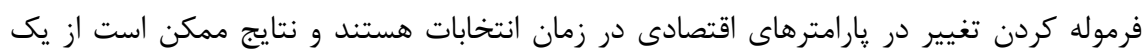

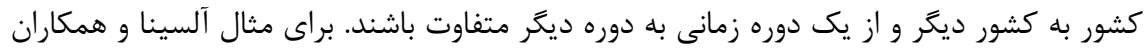

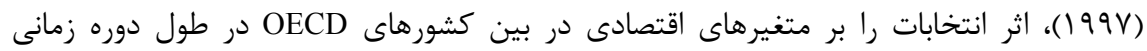

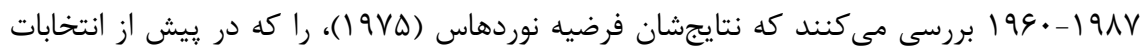

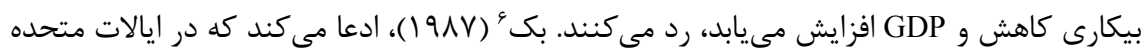

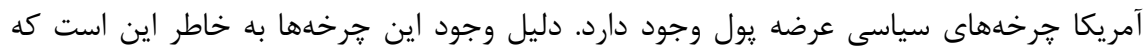

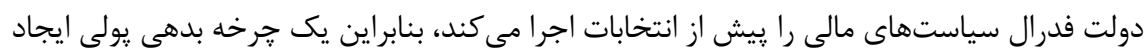

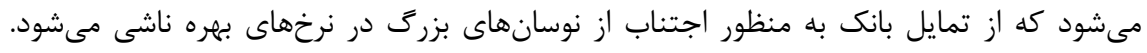

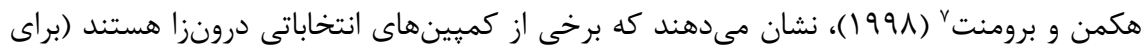

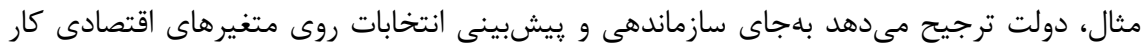

1. Cukierman \& Meltzer

2. Rogoff

3. Sibert

4. Persson \& Tabellini

5. Alesina et al.

6. Beck

$\checkmark \quad$ 7. Heckelman \& Berument 
كند و در صورتى كه سيگنالهاى اقتصادى مثبت باشند، آنها را ريش از انتخابات تحت تاثير قرار

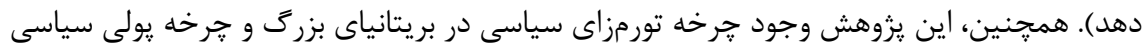

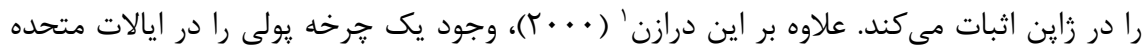

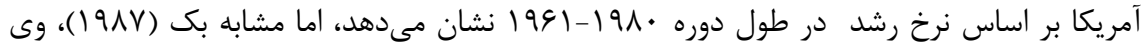

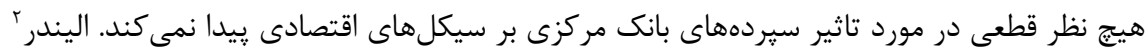

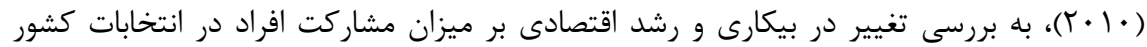

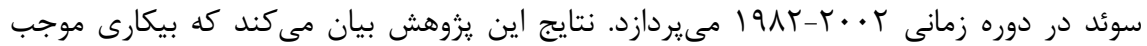
كاهش مشاركت مردم و رشد اقتصادى موجب افزايش مشاركت مردم در انتخابات مىشود. لايق

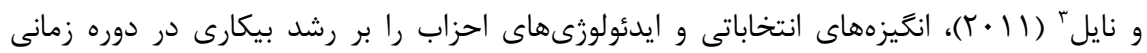

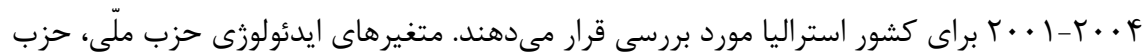

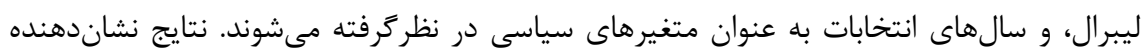
وجود رفتارهاى فرصتطلبانه در حزب حاكم است، بهكونهاى كه با كاهش بيكارى و افزايش بودجه

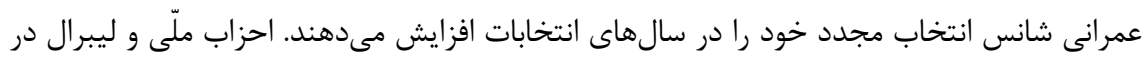

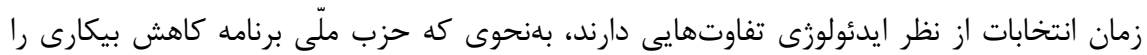
از طريق تخصيص بودجه دنبال مى كند، در حال كه ايدئولوزى حزب مقابل موجب افزايش بيكارى بهى

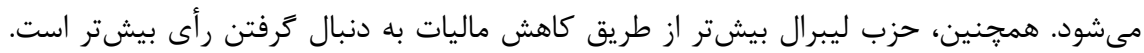

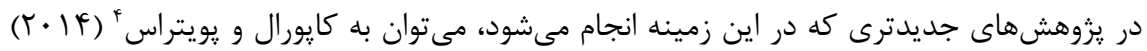

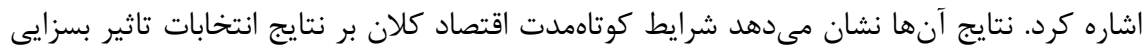

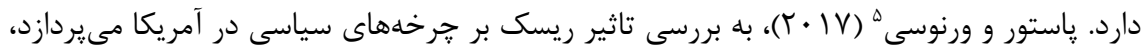

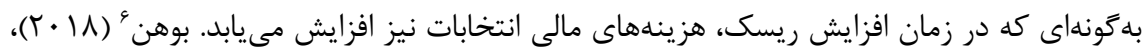
به بررسى اين موضوع مىيردازد كه مدلهاى انتظارهاى عقلايى نمىتوانند توضيح قانع كنندهاى بدهند كه جرا دستكارى در بودجههاى سياسى به صورت سيستماتيك شانس انتخاب مجدد را را در

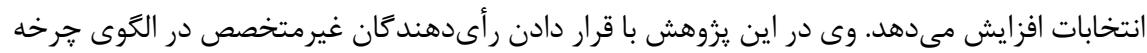

\section{Drazen}

2. Elinder

3. Leigh \& Neill

4. Caporale \& Poitras

5. Pastor \& Veronesi

6. Bohn 
سياسى فرصتطلب، اين مسئله را توضيح مىدهد. نتيجه كار به اين صورت است كه رأىدهندكان

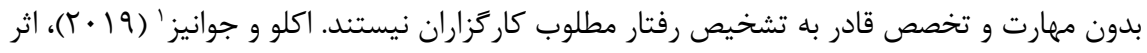

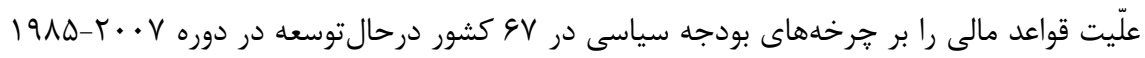

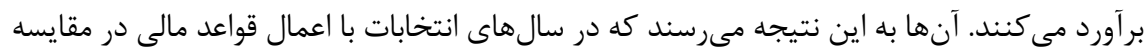

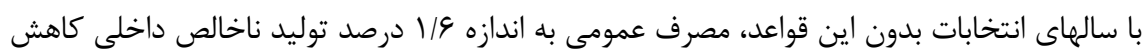

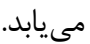

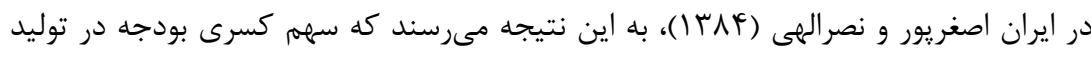

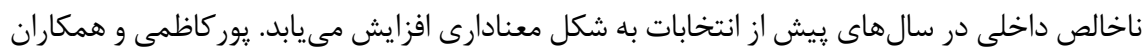

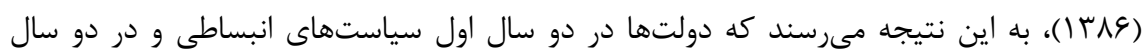

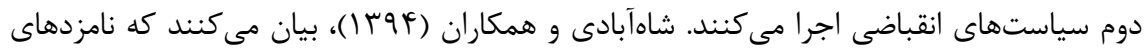

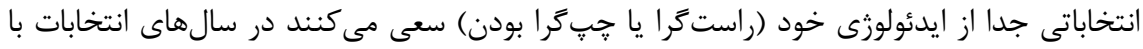

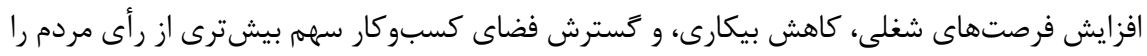

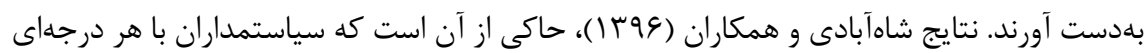

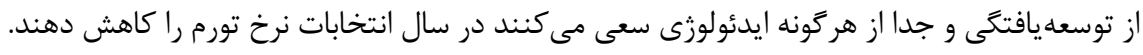

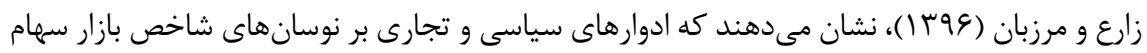

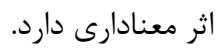

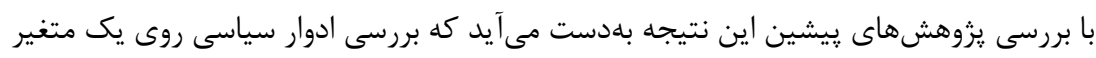

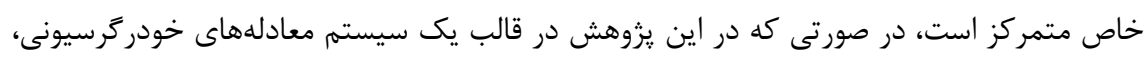

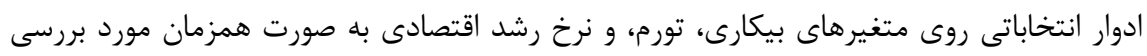

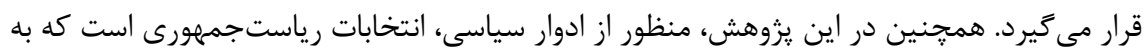
صورت يك متغير مجازى تعريف مى مودد.

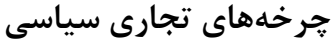

بررسى ادبيات نظرى در رابطه با خرخهاى تجارى سياسى حاكى از اين حقيقت است كه جهار

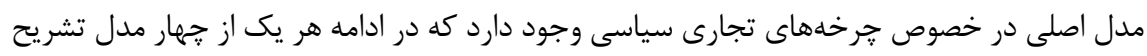


مدل فرصتطلبى ادوار تجارى نوردهاس (هVه)

اين مدل مى كوشد نشان دهد مسئولان دولت پيش از انتخابات سعى مى كنند با دستكارى اقتصاد

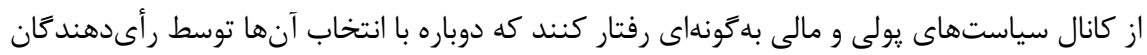
در قدرت باقى بمانند. در اين مدل، تلاش مىشود كه با كمك تابع هدف نامزدها و در قالب دو گزينه ممكن، يعنى كاهش تورم و ايجاد اشتغال، رفتار اقتصادى آنها بررسى شود. فروض اصلى مدل نوردهاس (9VD () به اين صورت است:

فرض ا. منحنى فيلييس در اقتصاد به صورت معادله (1) است:

$u_{t}=u+\alpha u_{t-1}+\gamma\left(\pi_{t}-\pi_{t}^{e}\right)+\varepsilon_{t} ; \quad \cdot \prec \alpha \prec 1 ; \quad \gamma \prec$

كه در آن u نرخ بيكارى، $\pi$ نرخ تورم، $u^{e}$

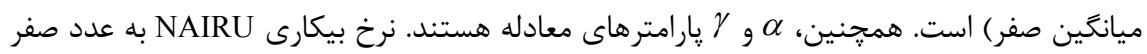

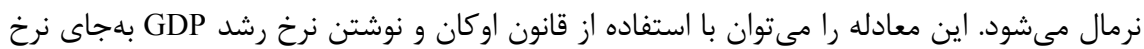
بيكارى بازنويسى كرد. فرض r. انتظارهاى تورمى از نوع تطبيقى است:

$\pi_{t}^{e}=\pi_{t-1}+\lambda\left(\pi_{t-1}^{e}-\pi_{t-1}\right) ; \quad \cdot \prec \lambda \prec$

فرض ب. روحيه سياستمداران يكسان است و ترجيح آنها اين است كه در قدرت باقى بمانند. سياستمداران و رأىدهندكان داراى تابع هدف يكسان هستند: $V_{t}=\sum_{i=.}^{\infty} \beta^{i} g\left(y_{t}, \pi_{t}\right), \quad \cdot \prec \beta \prec$

$$
\begin{aligned}
& \text { كه در آن } \beta \text { نرخ تنزيل رأىدهندكًان است. } \\
& \text { فرض أ. دولت به صورت مستقيم تورم را كنترل مى كند. }
\end{aligned}
$$

فرض ه. در جامعه سياستمداران فرصتطلب وجود دارند و سعى مى كنند در انتخابات برنده

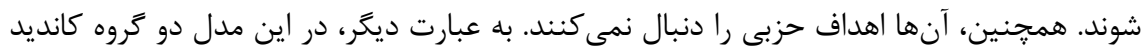

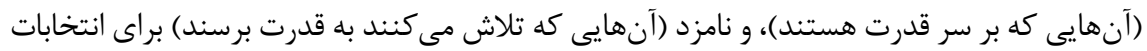

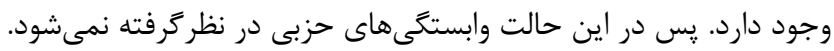

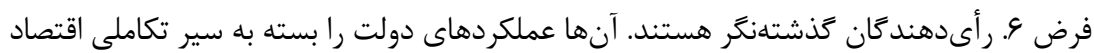
در انتخابات كذشته ارزيابى مى كنند. به عبارت ديكر، رأىدهندكان تورم و بيكارى را دوست ندارند و و بر اساس عملكرد حذشته سياستمداران (كذشتهُ نزديك) تصميم مى گئيرند. 


$$
\begin{aligned}
& \text { فرض V. زمان انتخابات به صورت برونزا تعيين مىشود }
\end{aligned}
$$

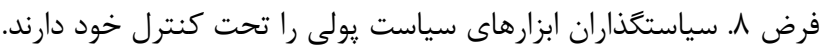

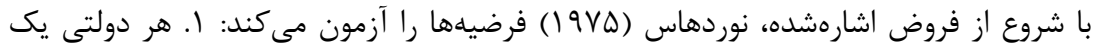
نوع سياست اقتصادى را مورد استفاده قرار مىدهد؛ r. زمانى كه دوره تعهد به پايان مىرسد، دولت

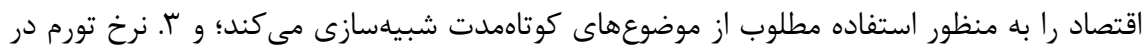
دوره انتخابات به عنوان نتيجه سياستهاى انبساطى افزايش مىيابد.

\section{مدل جرخههاى سياسى تجارى عقلايى}

يرسون و تابلينى (Y99(1)، در جهت اصلاح مدل نوردهاس (9VD(1)، يك مدل ساده تحت عنوان

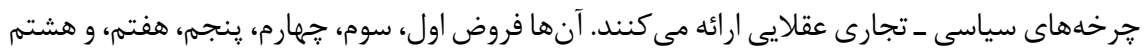
را حفظ و فروض دوم و ششم را به اين صورت اصلاح مى كنند: فرض 'rاي: انتظارهاى عقلايى)؛ فرض "rا:

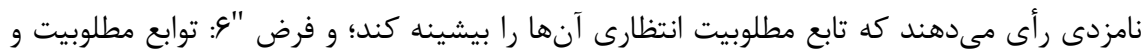
ترجيح رأى رهندكان يكسان است.

با فرض وجود انتظارهاى عقلايى در مدل، رفتار رأىدهندكان در مورد تورم عقلايى است، بلنحوى ئس كه از تمامى اطلاعات كذشته، حال، و آينده' در اين خصوص استفاده مى كنند. در اين حالت، ميان

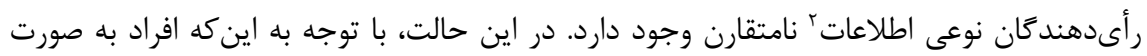
عقلايى رفتار مىكنند (تنها دوره انتخابات مبناى تصميمكيرى آنها نيست)، دولتمردان از انجام

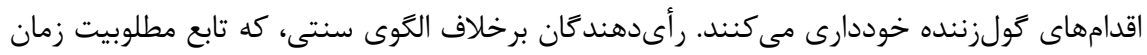

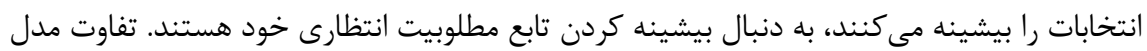

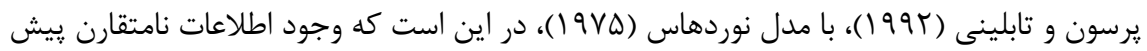

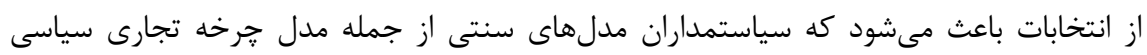

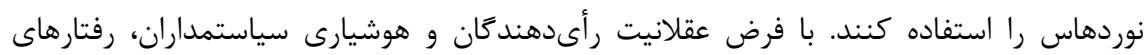

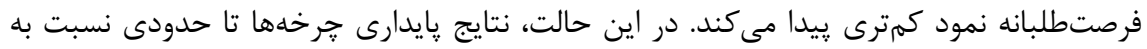
مدل نوردهاس بىنظهمتر است. 
روكوف و سيبرت' (91191)، سطوح كفايت ' را وارد مدل مى كنند و توازن بودجه را جايگزين تورم| بيكارى. آنها همجنين برخى از فروض را در مورد توزيع اطلاعات حفظ مى كنند. مدل آنها مطابق

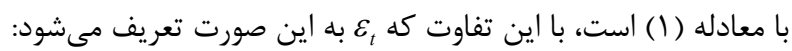

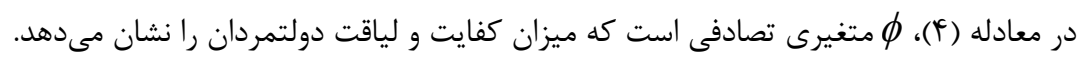

\section{مدل نظريه حزبى هيبس (19VV)}

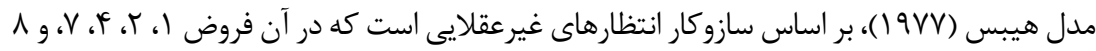
در مدل فرصتطلبى برقرار است و فروض ه و \& جايكزين مىشود. در اين مدل فرض مىشود كه سيستم سياسى كشور شامل دو حزب راست و جٍ است. حزب راست بيشتر به مبارزه با تورم و حزب جِ

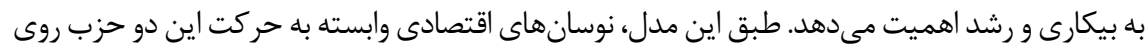

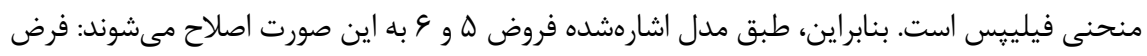

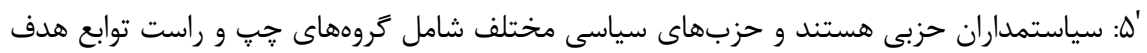

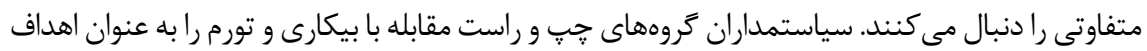

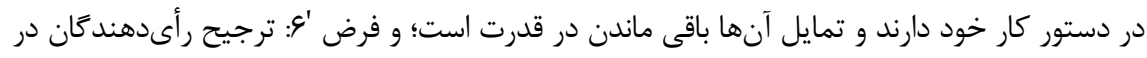

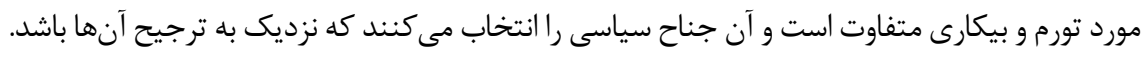

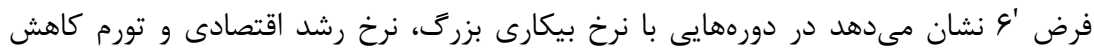
مىيابد. به عنوان يك نكته در مدل هيبس (19VV)، درآمدهاى طبقه متوسط افزايش ميى يابد و

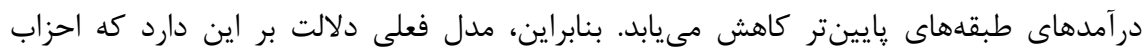

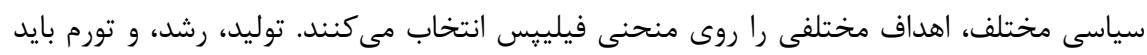

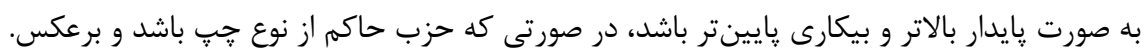

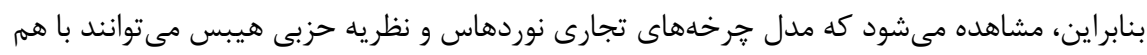
وجود داشته باشند. اگر فرض كنيم كه سياستمداران فرصتطلب و حزبى، و رأىدهندگان كذشتهنيكر هستند، و بهَونهاى فرض ينجمم برقرار باشد، در اين صورت مدل نوردهاس نسبت به مدل حزبى

مطلوبتر است (Frey \& Schneider, 1978).

1. Rogoff \& Sibert

2. Competencies 


\section{مدل نظريه حزبى آلسينا و همكاران (199V)}

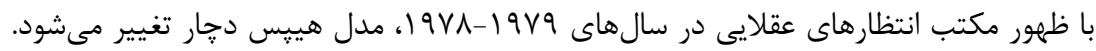

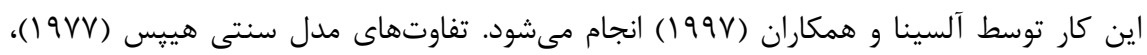

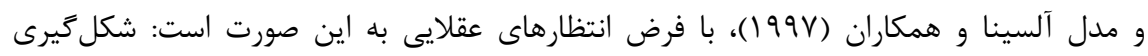
انتظارهاى تورمى به صورت عقلايى؛ و رأىدهندكان از تمامى اطلاعات كذشته، حال، و آينده استفاده مى كنند. هدف آنها بيشينه كردن مطلوبيت انتظارى است. تعديل انتظارها به صورت سريع انجام مىشود. بنابراين، در اين مدل يك دور' مى تواند طول عمر خيلى كوتاهى داشته باشد.

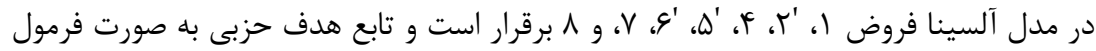

$$
W^{i}=\sum_{t} \delta^{t}\left[-\left(\pi_{t}-c^{i}\right)^{r}-b^{i}\left(u_{t}-K^{i}\right)^{r}\right], \quad \cdot \prec \delta \prec
$$

كه در آن I=L,R احزاب جٍٍ و راست را نشان مى دهد و محدوده t از صفر تا T است. مدل (ه)، زمانى يك جرخه سياسى ايجاد مى كند كه قراردادهاى كار در فواصل زمانى گسسته منعقد شود و نتايج انتخابات برآمده از شوكهاى درآمدى ترجيح رأىدهندكان يا نرخهاى مشاركت آنها دران در انتخابات باشد. ايده اصلى مدل اين است كه با فرض تعديل كم دستمزد، تغييرهاى مرتبط با رزيمهاى تورمى، باعث ايجاد انحرافهاى موقتى در فعاليتهاى واقعى اقتصاد از مقدار تعادلى آن مىشود.

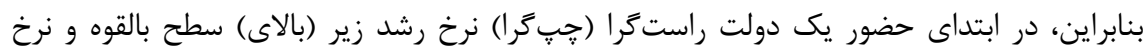
بيكارى بالاى (زير) سطح طبيعى آن قرار دارد.

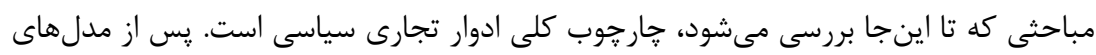

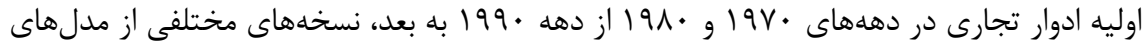

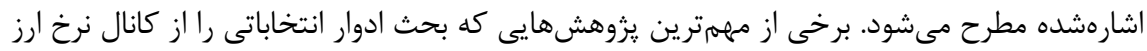

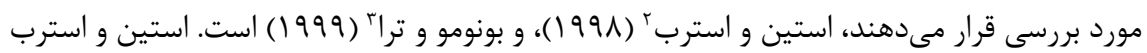
(991)، به اين موضوع مىيردازند كه تلاش سياستمداران در مدت زمان پيش از از انتخابات بر كند

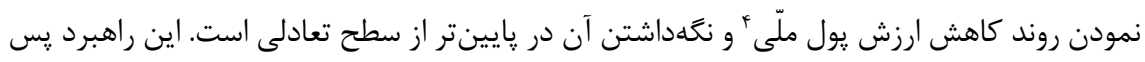
از انتخابات به كاهش شديد ارزش يول ملّى منجر مىشود. در نتيجه، نرخ ارز واقعى پيش ازيش از انتخابات

1. Cycle

2. Stein \& Streb 
داراى اضافه ارزش و يس از انتخابات دجار كاهش ارزش مىشود. بونومو و ترا (999 (1)، اقتصاد را به بخشهاى مبادلهيذير و مبادلهنايذير تقسيم مى كنند. آنها فرض مى كنند كه هر يك از إنى سياستمداران و رأى دهند

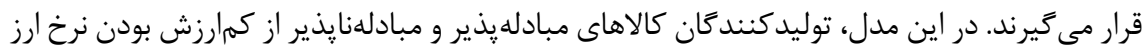

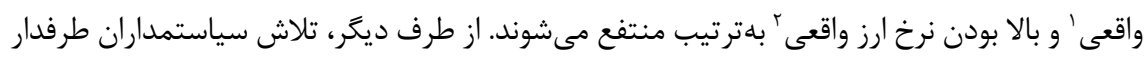
بخش مبادلهنايذير بر اين است تا خود را طرفدار بخش مبادلهيذير نشان دهند. بسته به زمانهاى

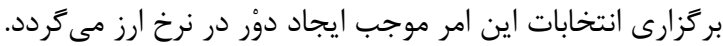

\section{شواهد تجربى از ادوار انتخاباتى بر روند متغيرهاى اقتصادى در ايران}

براى بررسى تجربى تاثير ادوار انتخاباتى بر متغيرهاى كلان اقتصادى، در نمودار ( ) روند متغيرهاى

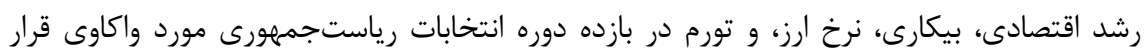

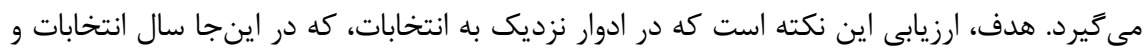

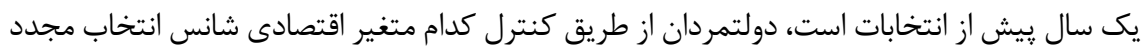
خود را افزايش مى دهند. از آنجا كه انتخابات رياستجمهورى در ايران در خرداد يا تير هر سال انجام

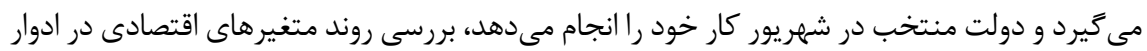

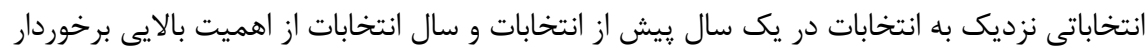
است. با توجه به نمودار (1) مشاهده مىشود كه دولتهايى كه احتمال انتخاب مجدد آنها براى دوره جهارساله وجود دارد، در سال انتهايى از جهار سال اول مديريت كشور، تمركز خود را بر كاهش تورم

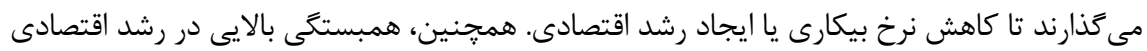

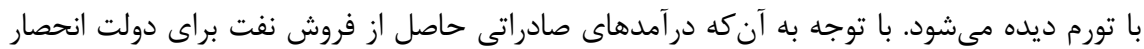
عرضه ارز را در بر دارد، دولت با كنترل نرخ ارز بهراحتى مىتواند تورم را در بازه مورد نظر نگَه دارد.

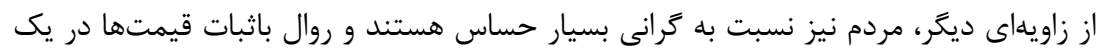

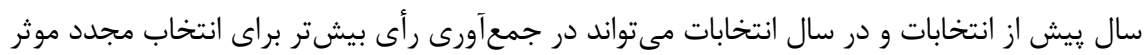
باشد. در واقع، متغير كنترلى دولتها در اقتصاد ايران رسيدن به هدف مورد تمايل خويش، يعنى تورم و نرخ ارز است. دولتها با در نظر داشتن حافظه كوتاهمدت رأىدهند 
و نرخ ارز در يك سال پيش از انتخابات احتمال انتخاب مجدد خويش را در انتخابات افزايش دهند. در خصوص دلايل تمايل دولتها به كنترل تورم و نرخ ارز در ادوار نزديك به انتخابات (منظور سال انتخابات و يك سال ييش از انتخابات)، بايد گفت كه مديريت تورم نسبت به ايجاد اشتغال سهلتر و در بازه زمانى كوتاهترى در اقتصاد نمود مى يابد و تحقق اهدافى جون كاهش بيكارى يا ايجاد رشد اقتصادى بالا، فرايندى بلندمدت است و مستلزم بهبود محيط كسبو كار و اصلاح سيستم ياداشدهى

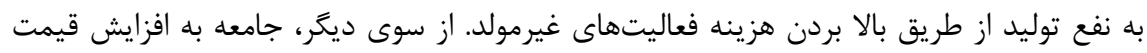

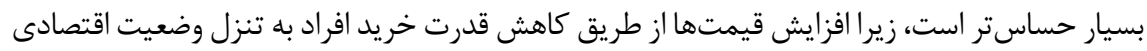
خانوارها و متعاقب آن افت سطح كيفى زندكى منجر ميىشود. همجنين، به واسطه آن كه اقتصاد كشور

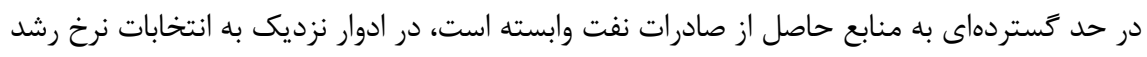

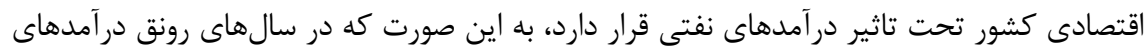
نفتى، افزايش رشد اقتصادى را شاهد هستيم و در سالهاى ركود درآمدهاى نفتى، رشد اقتصادى نيز

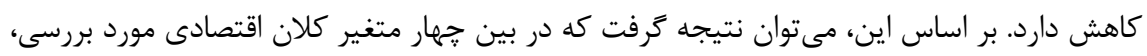

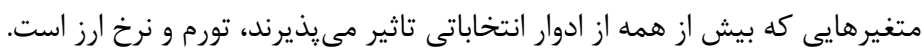

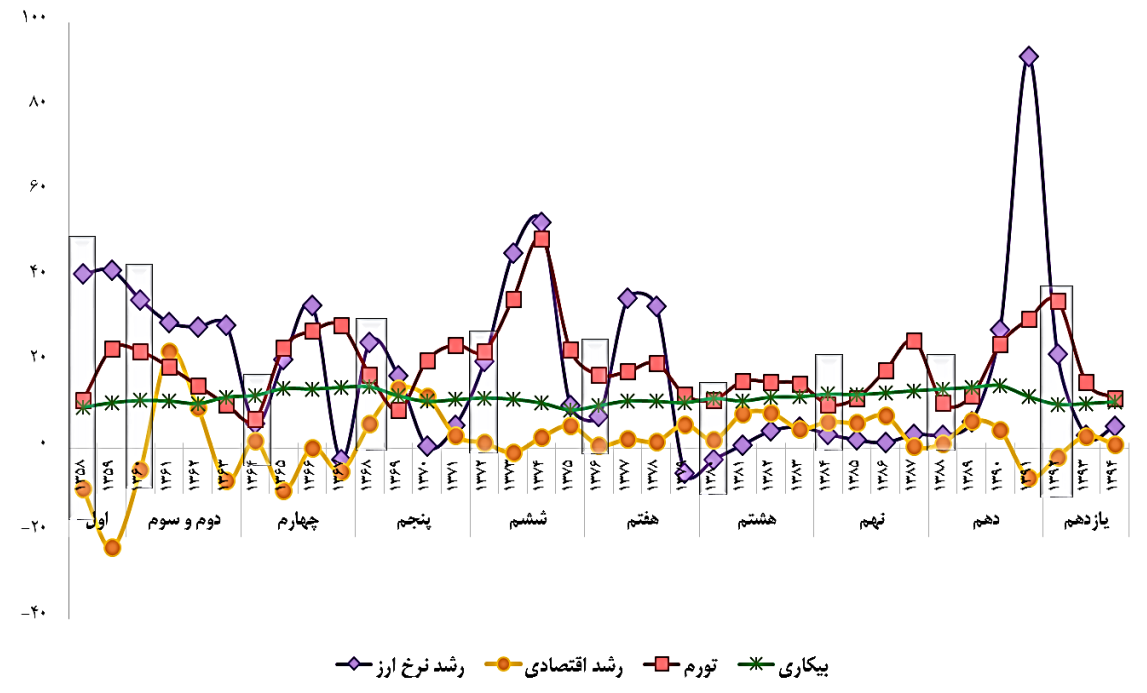




\section{روششناسى يزوهش و نتايج بر آورد مدل}

بهطور معمول، مدلهاى VAR به منظور مطالعه دادههاى كلان اقتصادى مورد استفاده قرار

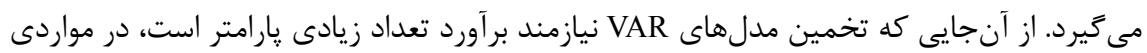
كه تعداد مشاهدهها كمم باشد، تخمين بيش از حد يارامترها فرايند تخمين را دجار مشكل ميى كند.

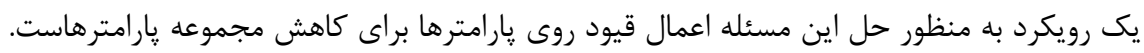

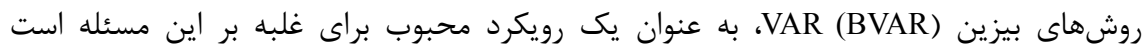

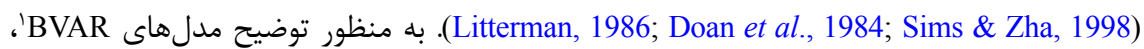
$y_{t}=a_{.}+\sum_{j=1}^{p} A_{j} y_{t-j}+\varepsilon_{t}$ مدل VAR(p) را در نظر بخيريد:

كه در آن $y_{t}$ و ع بردارهاى إس $m$ شامل متغيرهاى درونزا و جزء خطا هستند. براى سادگى،

$$
\begin{aligned}
& \text { معادله (9) را به اين صورت در نظر بخيريد: } \\
& Y=X A+E \\
& y=\left(I_{m} \otimes X\right) \theta+e
\end{aligned}
$$

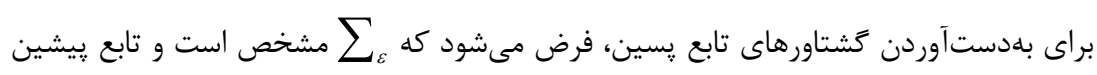

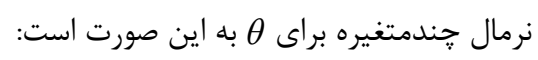

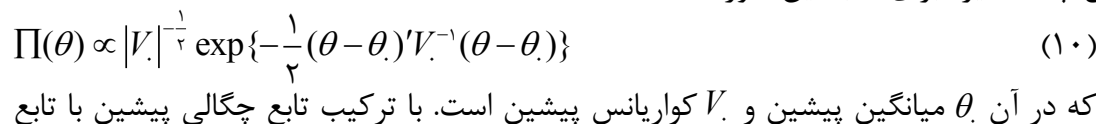

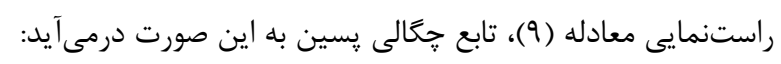
$\Pi(\theta \mid y)=\exp \left\{-\frac{1}{r} \cdot\left(\left(V^{-\frac{1}{r}}(\theta-\theta)\right)^{\prime}\left(V^{-\frac{1}{r}}(\theta-\theta).\right)+\left\{\left(\sum_{\varepsilon}^{-\frac{1}{r}} \otimes I_{T}\right) y-\left(\sum_{\varepsilon}^{-\frac{1}{r}} \otimes X\right) \theta\right\}^{\prime}\left\{\left(\sum_{\varepsilon}^{-\frac{1}{r}} \otimes I_{T}\right) y-\left(\sum_{\varepsilon}^{-\frac{1}{r}} \otimes X\right) \theta\right\}\right)\right\}$ 
افرادى مانند ليترمن (1919)، دون و همكاران (914F)، و سيمز و زا (1991)، روشهاى (191)

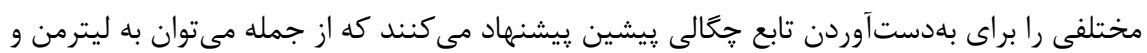

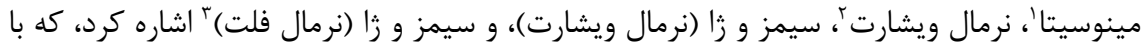

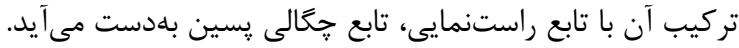

\section{بر آورد مدل و ارائه نتايج تجربى} به بيروى از مباحث نظرى و تجربى تصريح اقتصادسنجى برآورد مدل يزوهش به صورت رابطه $y_{t}=a+\sum_{j=1}^{p} A_{j} y_{t-j}+\sum_{j=1}^{q} B_{j} x_{t-j}+\varepsilon_{t}$

در معادله (r (1)، بردار ty شامل متغيرهاى درونزاى رشد اقتصادى، نرخ بيكارى، و نرخ تورم است.

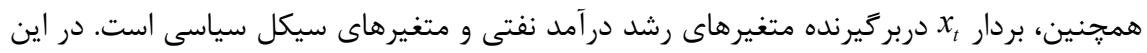
يزوهش، سيكل رياستجمههورى به عنوان متغير سياسى اثرگذار بر متغيرهاى اقتصادى در نظرگرفته

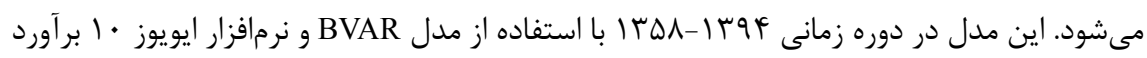

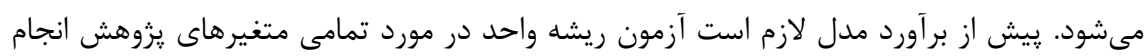

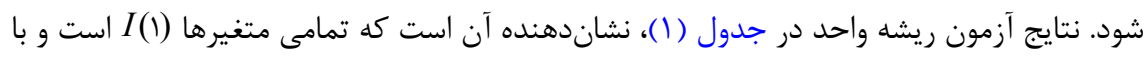
يك بار تفاضل كيرى مانا مىشوند.

\begin{tabular}{|c|c|}
\hline \multicolumn{2}{|c|}{ جدول 1: آزمون مانايى متغيرهاى يثوهش } \\
\hline آماره ديكى فولر & متغيرها \\
\hline$-Y / 9 Y(\cdot / \cdot 9)$ & نرخ رشد اقتصادى \\
\hline$-T / F \Delta(\cdot / 1 \cdot)$ & نرخ بيكارى \\
\hline$-T / Y \Lambda(\cdot / / T)$ & نرخ تورم \\
\hline$-I / T Y(\cdot / T I)$ & نرخ رشد درآمدهاى نفتى \\
\hline
\end{tabular}

1. Litterman \& Minnesota 
به يِيروى از سيمز' (•191()، و سيمز و همكاران' (•991)، براى بررسى روابط متقابل بين متغيرها با وجود ريشه واحد و بدون نياز به تفاضل

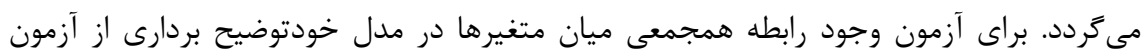

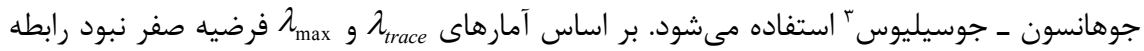
همجمعى براى تمامى مدلها رد مىشود. نتايج در جدول (Y) كزارش مىشود.

جدول r: آزمون همكرايى جوهانسون-جوسيليوس

\begin{tabular}{|c|c|c|c|c|}
\hline 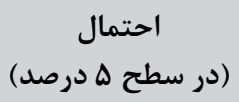 & 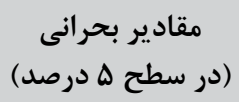 & $\begin{array}{c}\text { مقادير آماره } \\
\lambda_{\text {Trace }}\end{array}$ & مقادير ويثه & فرضيهها \\
\hline$\cdot / \cdot r$ & rq/Vq & $f \cdot / 4 \Delta$ & $\cdot 1049$ & None \\
\hline$\cdot / \cdot \Delta$ & $10 / 4 q$ & $1 \Delta / \Delta \Delta$ &.$/ 48$ & At most 1 \\
\hline 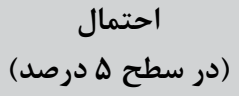 & 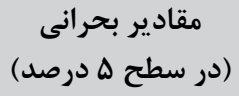 & $\begin{array}{c}\text { مقادير آماره } \\
\lambda_{\text {Max }}\end{array}$ & مقادير ويثه & فرضيهها \\
\hline $.1 \cdot 1$ & $r \mid / T$ & $r r / q$. & $\cdot \mid \Delta T$ & None \\
\hline .119 & $\mid F / T 4$ & $1 \cdot \pi / 4$ &.$/ 48$ & At most 1 \\
\hline
\end{tabular}

همجنين، بر اساس معيارهاى اطلاعات (آكائيك؟، شواتزه، و هنان كويين؟)، و معيار خطاى ريشبينى وقفه بهينه مدل ( () است. بنابراين، مدل نهايى :يزوهش به اين صورت درميى آيد: $\left[\begin{array}{c}G_{t} \\ I n f_{t} \\ U n_{t}\end{array}\right]=\left[\begin{array}{c}\alpha_{1} \\ \alpha_{r} \\ \alpha_{r}\end{array}\right]+\left[\begin{array}{lll}\beta_{11} & \beta_{1 r} & \beta_{r r} \\ \beta_{r 1} & \beta_{r r} & \beta_{r r} \\ \beta_{r 1} & \beta_{r r} & \beta_{r r}\end{array}\right]\left[\begin{array}{c}G_{t-1} \\ I n f_{t-1} \\ U n_{t-1}\end{array}\right]+\left[\begin{array}{ll}\gamma_{11} & \gamma_{r r} \\ \gamma_{r 1} & \gamma_{r r} \\ \gamma_{r 1} & \gamma_{r r}\end{array}\right]\left[\begin{array}{c}\operatorname{Pr}_{t} \\ O r\end{array}\right]+\left[\begin{array}{c}\varepsilon_{t}^{G} \\ \varepsilon_{t}^{I n f} \\ \varepsilon_{t}^{U n}\end{array}\right]$ در معادله (r (1)، متغيرهاى درونزا شامل G نرخ رشد اقتصادى، Inf نرخ تورم، و Un نرخ بيكارى است.

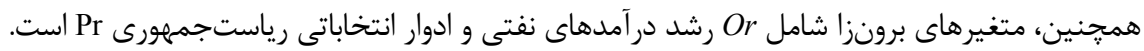
متغير مجازى Pr به اين صورت تعريف مىشود كه در سال انتخابات رياستجمهورى عدد ا و در بقيه

1. Sims

2. Sims et al.

3. Johansen- Juselius

4. Akaike

5. Schwarz

6. Hannan-Quinn 
سال ها عدد • در نظرگرفته مىشود. متغيرهاى

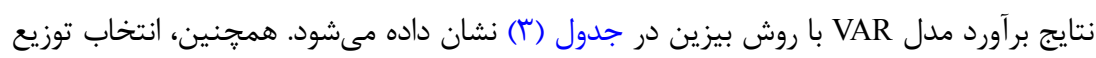
پيشين بر مبناى ليترمن - مينوسيتا صورت مى گيرد. با توجه به نتايج مشخص مىشود كه در آمدهاى

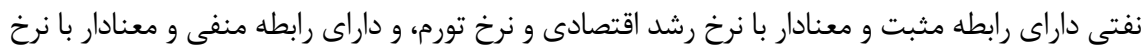

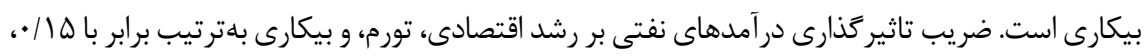

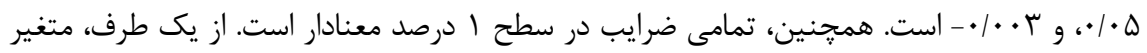

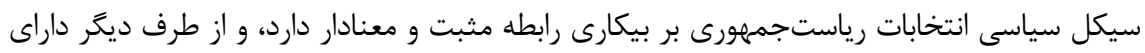

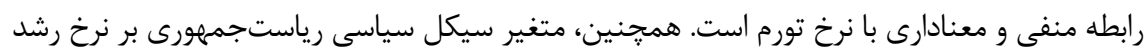

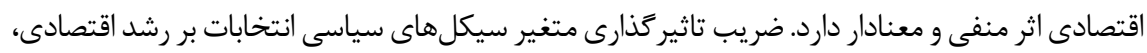

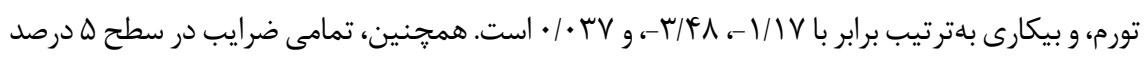

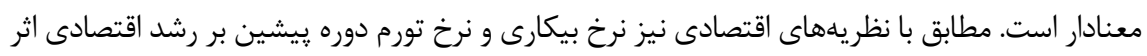

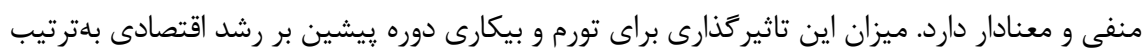

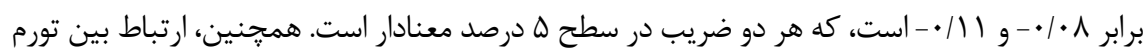

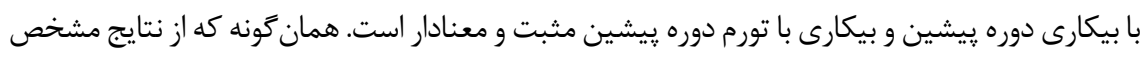
است، اثر سيكلهاى سياسى بر تورم نسبت به رشد اقتصادى و بيكارى شديدتر است كه تاييدكننده نتايج

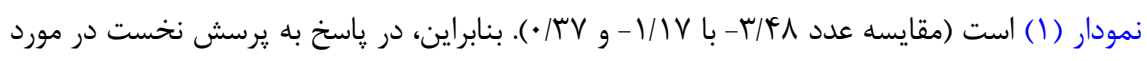
اين كه آيا رفتار دولتها يِيش از انتخابات مى تواند بر روند متغيرهاى كلان اقتصادى كشور موثر واقع گرددد،

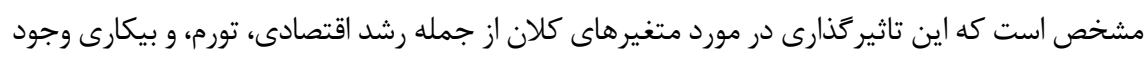

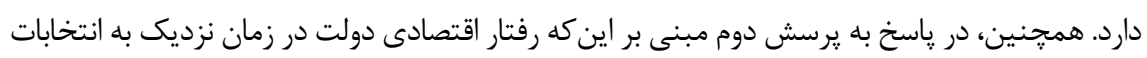

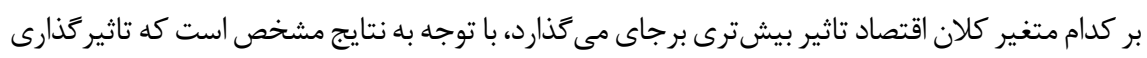
سيكل هاى سياسى بر تورم نسبت به رشد اقتصادى و بيكارى بيشتر ميثر است.

جدول ץ: نتايج بر آورد مدل با روش BVAR

\begin{tabular}{|c|c|c|c|}
\hline$U n_{t}$ & $\operatorname{Inf} f_{t}$ & $G_{t}$ & متغيرها \\
\hline$-\cdot / \cdot \cdot \Delta(\cdot / \cdot 1)$ & $-\cdot / 19(\cdot / \cdot f)$ & $\cdot / 19 \wedge(\cdot / \cdot \vee)$ & $G_{t-1}$ \\
\hline$\cdot / \cdot 1 \vee(\cdot / \cdot \cdot 9)$ & $\cdot / 1 Q(\cdot / \cdot F)$ & $-\cdot / \cdot \Lambda(\cdot / \cdot \Delta)$ & $\operatorname{Inf} f_{t-1}$ \\
\hline$-\cdot / r V(\cdot / \cdot V)$ & $\cdot \mid F \mu(\cdot 1 \cdot 9)$ & $-\cdot / 11(\cdot / \cdot 4)$ & $U n_{t-1}$ \\
\hline
\end{tabular}


ادامه جدول rا: نتايج برآورد مدل با روش BVAR

\begin{tabular}{|c|c|c|c|}
\hline$U n_{t}$ & $\operatorname{Inf} f_{t}$ & $G_{t}$ & متغير ها \\
\hline$-\cdot / \cdot r r(\cdot / \cdot \cdot r)$ & $\cdot / \cdot \Delta(\cdot / \cdot r)$ & $\cdot / 1 Q(\cdot / \cdot r)$ & $O r_{t}$ \\
\hline$\cdot / r V(\cdot / \cdot 1)$ & $-r / \mathcal{F} \Lambda(\cdot / \cdot r)$ & $-1 / / V(\cdot / \cdot r)$ & $\operatorname{Pr}_{t}$ \\
\hline$V / V I(\cdot / 1 \cdot)$ & $|Y / \Delta|(\cdot / \cdot \Lambda)$ & $1 / \pi 1(\cdot / \cdot 9)$ & عرض از مبدا \\
\hline
\end{tabular}

نكته: مقادير داخل برانتز نشاندهنده مقادير احتمال است.

در جدول (f)، معيارهاى نيكى برازش مدل شامل آزمون نرمال بودن باقيماندهها (آماره جارك ـ

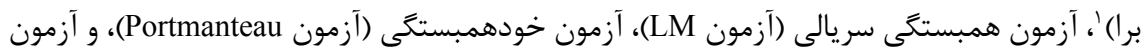

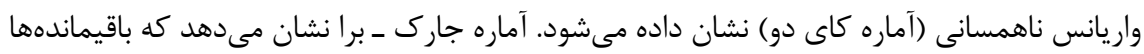

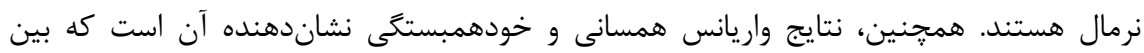

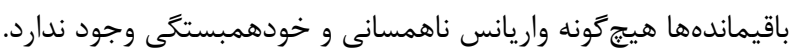

جدول ^: نتايج آزمونهاى نيكى برازش مدل

\begin{tabular}{|c|c|}
\hline آماره & 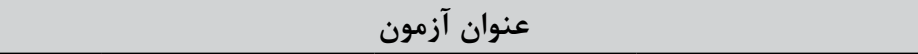 \\
\hline$f / \mid V(\cdot / / \psi)$ & آزمون نرمال بودن باقيماندهها (آماره مشترك جارك ـ برا) \\
\hline$f / r \wedge(\cdot / 11)$ & آماره نسبت درستنمايى وقفه 1 \\
\hline$Y / \cdot r(\cdot / \cdot \Lambda)$ & 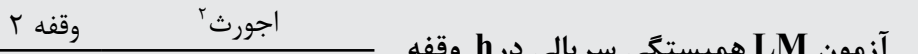 \\
\hline$\cdot / F \wedge(\cdot / / r)$ & 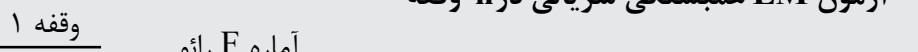 \\
\hline$\cdot / 1 \%(\cdot / 19)$ & وقفه r \\
\hline$r / 1 Y(\cdot / / \Delta)$ & آماره نسبت درستنمايى لوقفه 1 \\
\hline$f / T I(\cdot / l f)$ & 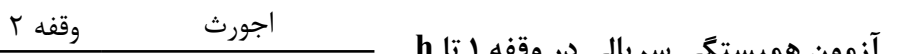 \\
\hline$\cdot 101(\cdot / 1 \cdot)$ & وقفه 1 \\
\hline$\cdot / 1 T(\cdot / / \Delta)$ & وقفه r \\
\hline $4 / T I(\cdot / 1 \Lambda)$ & Dontmontoou =.. \\
\hline$r / T r(\cdot / K \Lambda)$ & آماره Q تعديلشده \\
\hline$G \wedge / 1 \wedge(\cdot / T 1)$ & بدون جملههاى متقاطع \\
\hline$|9 N| \cdot V(\cdot / 1 \cdot)$ & با جملههاى متقاطع \\
\hline
\end{tabular}

1. Jarque-Bera

2. Edgeworth 
امروزه يزوهشهاى بينرشتهاى از جمله بررسى ادوار تجارى ـ سياسى در قالب اقتصاد سياسى

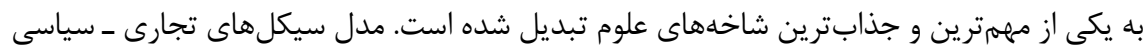

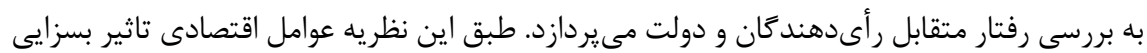

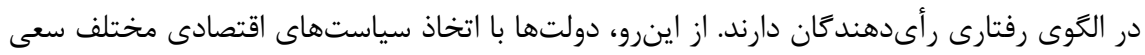

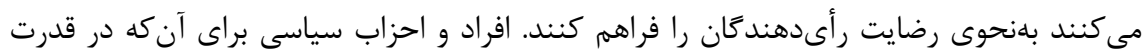

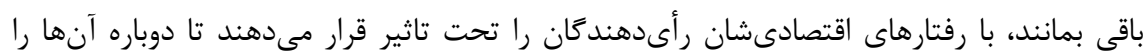
انتخاب نمايند. هدف از يزوهش حاضر، واكاوى تاثير وقوع ادوار انتخاباتى بر متغيرهاى كلان ران اقتصاد رادي

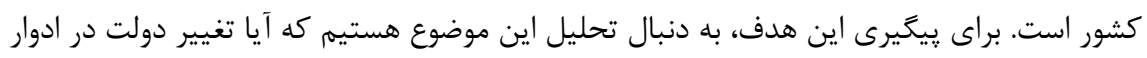

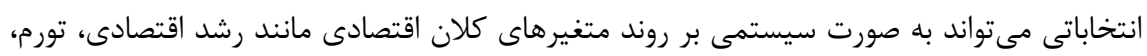

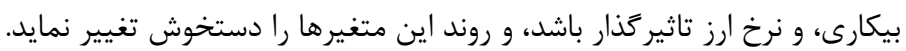

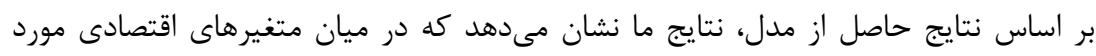

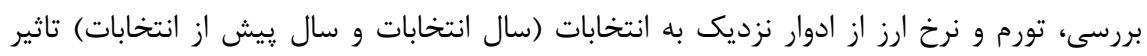
مى يذيرند. در واقع، متغير كنترلى دولتها در اقتصاد ايران رسيدن به هدف مورد تمايل خويش، يعنى

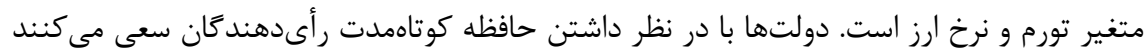
با كنترل تورم و نرخ ارز در يك سال ييش از انتخابات، احتمال انتخاب مجدد خويش رداب را در انتخابات افزايش دهند. در خصوص دلايل تمايل دولتها به كنترل تورم و نرخ ارز در ادوار نزديك به به انتخابات

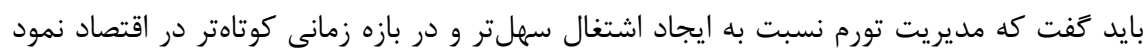
مى يابد و تحقق اهدافى جون كاهش بيكارى يا ايجاد رشد اقتصادى، فرايندى بلندمدت است. جامعه

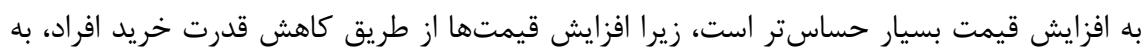
تنزل وضعيت اقتصادى خانوارها و افت سطح كيفى زندگى منجر مي شودي

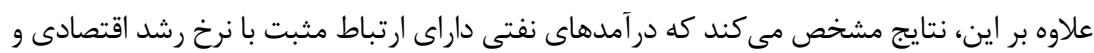

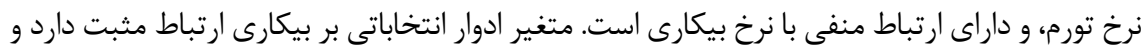

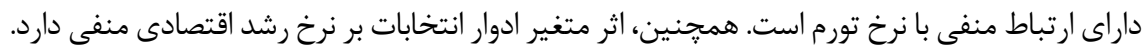

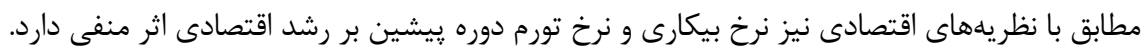

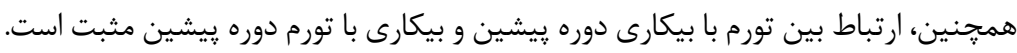


در مجموع نتايج بيان مى كند كه اگر دولتها سياستهاى خود را در راستاى كسب بيشينهُ آرا

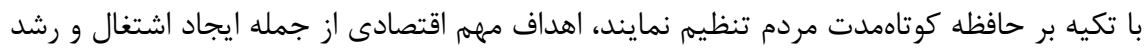
اقتصادى را در اولويتهاى بعدى قرار مىدهند. از اينرو، در راستاى ايجاد ثبات در اقتصاد و كاهش مردي اثر ادوار انتخاباتى بر متغيرهاى كلان اقتصادى ييشنهاد مى گردد بانك مركزى بـى به عنوان متولى ايجاد

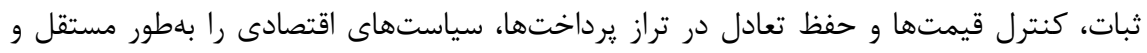
بر اساس اهداف بلندمدت تنظيم كند تا منافع بلندمدت جامعه تحت تاثير سياستهاى انتخاباتى

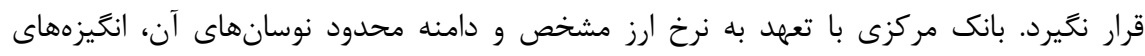

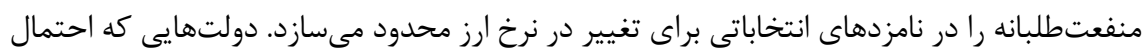

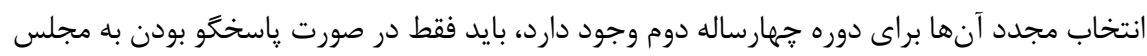

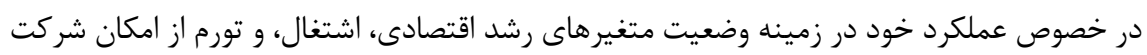

$$
\text { مجدد در انتخابات بهرممند كردند. }
$$

با توجه به موارد يادشده، يروهشهاى دآ آتى ميىتوانند به اين موضوع تمركز كنند كه تا جه ميزان

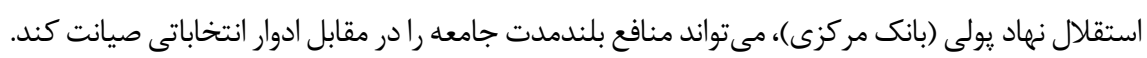

\section{الف) فارسى}

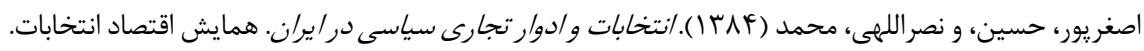

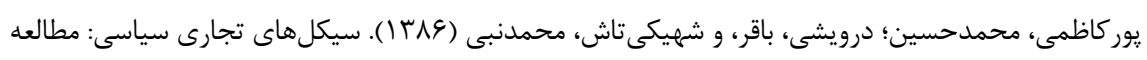

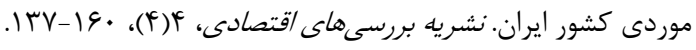

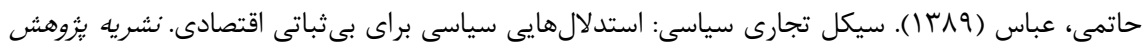

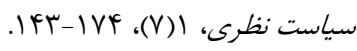

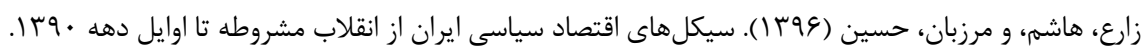

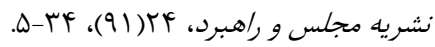

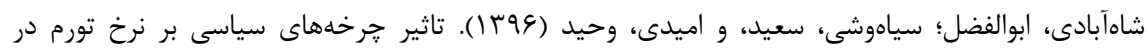

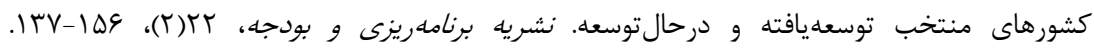
http://jpbud.ir/article-1-1361-fa.html

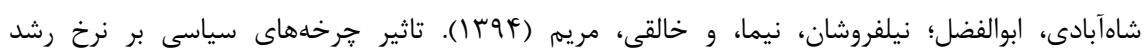




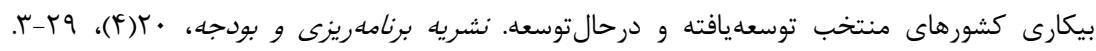
http://jpbud.ir/article-1-1226-fa.html

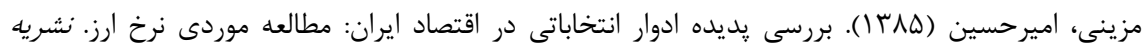

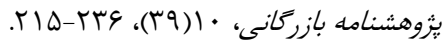

Alesina, A., Roubini, N., \& Cohen, G. D. (1997). Political Cycles and the Macroeconomy: MIT Press.

Beck, N. (1987). Elections and The Fed: Is There a Political Monetary Cycle? American Journal of Political Science, 31(1), 194-216.

Bohn, F. (2018). Political Cycles: Beyond Rational Expectations. PloS One, 13(10), e0203390. https://doi.org/10.1371/journal.pone.0203390

Bonomo, M., \& Terra, C. (1999). The Political Economy of Exchange Rate Policy in Brazil: An Empirical Assessment. Revista Brasileira de Economia, 53(4), 411-432.

Brender, A., \& Drazen, A. (2005). Political Budget Cycles in New Versus Established Democracies. Journal of Monetary Economics, 52(7), 1271-1295. https://doi.org/10.1016/j.jmoneco.2005.04.004

Caporale, T., \& Poitras, M. (2014). Voter Turnout in US Presidential Elections: Does Carville's Law Explain the Time Series? Applied Economics, 46(29), 3630-3638. https://doi.org/10.1080/00036846.2014.937037

Cukierman, A., \& Meltzer, A. H. (1986). A Theory of Ambiguity, Credibility, and Inflation under Discretion and Asymmetric Information. Econometrica: Journal of the Econometric Society, 54(5), 1099-1128.

De Donder, P., \& Hindriks, J. (2007). Equilibrium Social Insurance with PolicyMotivated Parties. European Journal of Political Economy, 23(3), 624-640. https://doi.org/10.1016/j.ejpoleco.2007.02.002

Doan, T., Litterman, R., \& Sims, C. (1984). Forecasting and Conditional Projection Using Realistic Prior Distributions. Econometric Reviews, 3(1), 1-100. https://doi.org/10.1080/07474938408800053

Drazen, A. (2000). The Political Business Cycle after 25 Years. NBER Macroeconomics Annual, 15(1), 75-117.

Eklou, K., \& Joanis, M. (2019). Do Fiscal Rules Cause Fiscal Discipline Over the Electoral Cycle? IMF Working Paper No. 19/291.

Elinder, M. (2010). Local Economies and General Elections: The Influence of Municipal and Regional Economic Conditions on Voting in Sweden 1985-2002. European Journal of Political Economy, 26(2), 279-292. https://doi.org/10.1016/j.ejpoleco.2010.01.003

Frey, B. S., \& Schneider, F. (1978). An Empirical Study of Politico-Economic Interaction in the United States. The Review of Economics and Statistics, 60(2), 174-183.

Garrett, G., \& Lange, P. (1989). Government Partisanship and Economic Performance: When and How Does" Who Governs" Matter? The Journal of Politics, 51(3), 676-693. 
Elections. Southern Economic Journal, 64(4), 987-1000.

Hibbs Jr, D. A. (1977). Political Parties and Macroeconomic Policy. The American Political Science Review, 71(4), 1467-1487. https://doi.org/10.1017/S0003055400269712

Immergut, E. M., \& Jochem, S. (2006). The Political Frame for Negotiated Capitalism: Electoral Reform and the Politics of Crisis in Japan and Sweden. Governance, 19(1), 99-133. https://doi.org/10.1111/j.1468-0491.2006.00305.x

Leigh, A., \& Neill, C. (2011). Can National Infrastructure Spending Reduce Local Unemployment? Evidence from an Australian Roads Program. Economics Letters, 113(2), 150-153. https://doi.org/10.1016/j.econlet.2011.05.037

Lindbeck, A. (1976). Stabilization Policy in Open Economies with Endogenous Politicians. The American Economic Review, 66(2), 1-19.

Litterman, R. B. (1986). Forecasting with Bayesian Vector Autoregressions-Five Years of Experience. Journal of Business \& Economic Statistics, 4(1), 25-38. https://doi.org/10.1080/07350015.1986.10509491

Nordhaus, W. D. (1975). The Political Business Cycle. The Review of Economic Studies, 42(2), 169-190.

Pastor, L., \& Veronesi, P. (2017). Political Cycles and Stock Returns (0898-2937). NBER Working Paper Series, No, 23184

Persons, W. M. (1926). Theories of Business Fluctuations: I. A Classification of the Theories. The Quarterly Journal of Economics, 41(1), 94-128. https://doi.org/10.2307/1885554

Persson, T., \& Tabellini, G. (1992). The Politics of 1992: Fiscal Policy and European Integration. The Review of Economic Studies, 59(4), 689-701. https://doi.org/10.2307/2297993

Potrafke, N. (2010). The Growth of Public Health Expenditures in OECD Countries: Do Government Ideology and Electoral Motives Matter? Journal of Health Economics, 29(6), 797-810. https://doi.org/10.1016/j.jhealeco.2010.07.008

Rogoff, K. (1987). Equilibrium Political Budget Cycles (0898-2937). NBER Working Paper Series, No. 2428

Rogoff, K., \& Sibert, A. (1988). Elections and Macroeconomic Policy Cycles. The Review of Economic Studies, 55(1), 1-16. https://doi.org/10.2307/2297526

Sibert, A. (1992). Government Finance in a Common Currency Area. Journal of International Money and Finance, 11(6), 567-578. httns://doi.org/10.1016/0261-5606(92)90004-H

Sims, C. A. (1980). Macroeconomics and Reality. Econometrica: Journal of the Econometric Society, 48(1), 1-48.

Sims, C. A., \& Zha, T. (1998). Bayesian Methods for Dynamic Multivariate Models. International Economic Review, 39(4), 949-968.

Sims, C. A., Stock, J. H., \& Watson, M. W. (1990). Inference in Linear Time Series Models with Some Unit Roots. Econometrica: Journal of the Econometric Society, 58(1), 113-144.

Stein, E. H., \& Streb, J. M. (1998). Political Stabilization Cycles in HighInflation Economies. Journal of Development Economics, 56(1), 159-180. https://doi.org/10.1016/S0304-3878(98)00057-1 